\title{
Core Self-Evaluations, life satisfaction, and sport satisfaction
}

\section{“CORE” auto-evaluación y satisfacción por la vida y el deporte}

\author{
Nicolas Baudin ${ }^{1}$, Angel Blanch ${ }^{2,3}$, Jean-Pierre Rolland ${ }^{1}$, Maite Martí-Guiu ${ }^{2,3}$ and Antón Aluja ${ }^{2,3}$ \\ ${ }^{1}$ Centre de Recherche sur le Sport et le Mouvement. Université Paris Ouest Nanterre La Défense, UFR STAPS, France. \\ ${ }^{2}$ Department of Psychology, University of Lleida, Catalonia, Spain. \\ ${ }^{3}$ Institut de Recerca Biomèdica de Lleida (IRB-Lleida), Catalonia, Spain.
}

Disponible online 31 de diciembre de 2014

\begin{abstract}
We investigated the association between Core Self-Evaluations (CSE) and life and sport satisfaction to assess whether the Core Self-Evaluations scale was a better predictor of life satisfaction or sport satisfaction. The study included three hundred and thirteen athletes (231 men and 82 women; age range to 47 years (Mage=22.9 years, SDage=5.9 years)). Participants completed the French language version of the CSE scale, the Satisfaction with Life Scale, and the Satisfaction with Sport Scale. As demonstrated in previous studies, life satisfaction and sport satisfaction were highly correlated. Path analyses showed that CSE was a strong predictor of life and sport satisfaction when integrated in a structural equation model. In a combined structural model, CSE predicted $39 \%$ and $13 \%$ of the variance in life satisfaction and sport satisfaction, respectively. The results suggest that CSE is a good predictor of life satisfaction. The results are discussed in the theoretical context of CSE, life satisfaction, and sport satisfaction.
\end{abstract}

Key words: Personality Dimensions; Personality Facets; Life Satisfaction; Well-Being; Sport Satisfaction.

Se examinan las relaciones entre el Core self-evaluation (CSE) y satisfacción de vida y al deporte para comprobar si el Core self-evaluation era un buen predictor para la satisfación de la vida y el deporte. Participaron en el estudio trescientos trece atletas (231 hombres y 82 mujeres) con una edad que va de 17 a 47 años ( $M=22.9, S D=5.9)$. Los participantes completaron la versión francesa del CSE, las escalas de satisfacción con la vida y la escala de satisfacción con el deporte. De acuerdo con los estudios anteriores, la satisfacción de vida y satisfacción del deporte estuvieron altamente correlacionadas. Los análisis de modelos de ecuaciones estructurales demostraron que el CSE era un buen predictor de satisfacción con la vida y el deporte. Una combinación de diferentes modelos estructurales informó que el CSE predecía el $39 \%$ de satisfacción de vida y el 13\% de la de satisfacción de deporte respectivamente. Los resultados del estudio presente sugieren que CSE es un buen predictor de la satisfacción a la vida. Se discuten los resultados en el ámbito teórico del CSE y la satisfacción de la vida, incluyendo la satisfacción por el deporte.

Key words: Dimensiones de Personalidad; Facetas de Personalidad; Satisfacción con la Vida; Bienestar; Satisfacción con el Deporte.

Correspondence concerning this article should be addressed to: Anton Aluja. Departament de Psicologia. Campus de Cappont. Estudi General, 4. 25001 Lleida. E-mail: aluja@pip.udl.cat. Authors’s E-mails: Nicolas Baudin: nicolasbaudin@wanadoo.fr; Angel Blanch: ablanch@pip.udl.cat; JeanPierre Rolland: rolland.jeanpierre@gmail.com; Maite Martí-Guiu : mtmarti@pip.udl.cat. 
Research on the dispositional source of Life Satisfaction has had a long history and it is integrated in the field of Subjective Well-Being (SWB). This body of research has demonstrated that the Extraversion and Neuroticism dimensions of personality were the strongest predictors of Happiness and that Neuroticism and Conscientiousness were the strongest predictors of Life Satisfaction based on the Five Factor model of personality (Steel, Schmidt \& Shultz, 2008). Research indicates that Life Satisfaction can be viewed as the result, in part, of satisfaction with various life domains, as work, family, health, physical activity and sports, among others. Thus, core self-evaluation represents satisfaction with the self, so, it should influence life satisfaction in other life domains (Andrews \& Withey, 1976; Campbell, Converse, \& Rodgers, 1976).

This notion was based on the assumption that individuals evaluate the details of experience when making overall satisfaction judgments (Rice, McFarlin, Hunt, \& Near, 1985). For most people, work is a central life activity (Dubin, 1956) and job satisfaction is the domain which received the most interest in the field.

The influence of personality as well as the different events of life gave rise to two hierarchical models of Subjective Wellbeing: the Bottom-Up and Top-Down models (Diener, 1984). According to the Bottom-Up theory, global feelings of wellbeing are the result of favorable events and living conditions. In other words, satisfaction and Happiness are the result of a life containing numerous moments (or conditions) of Happiness in a variety of realms: family, couple, incomes or work. From this perspective, the events and "the objective" conditions of life are the essential determinants of Well-Being (Rolland, 2000). The Top-Down perspective defends the inverse hypothesis: peoples have a stable predisposition to interpret life experiences, and to react to them either in a positive or in a negative way. This general tendency affects the evaluation of the events arising in various domains of life. From this perspective, the subjective interpretations of the events rather than the "objective" events themselves determine the Subjective Well-Being. A recent study showed that previous research underestimated the relation between personality and Subjective well-being, indicating that total Subjective Well-Being corrected variance accounted for by personality can reach as high as $39 \%$ or $63 \%$ (Steel et al., 2008). Another argument for this perspective is the long term stability of Happiness (Lyubomirsky, Sheldon \& Schkade, $2005)$, with genetic factors accounting for $80 \%$ of this stability (Lykken \& Tellegen, 1996). According to Heller, Watson and Ilies (2004) a comprehensive model of Life Satisfaction need to include the role of broad individual differences in personality (Top-Down) as well as the links between domain satisfactions and life satisfaction (Bottom-Up).

One recent approach on the dispositional sources of Job and Life Satisfaction focuses on a broad personality trait termed core self-evaluations (CSE; Judge, Locke, \& Durham, 1997). According to Judge et al. (1997), the CSE concept, which was originally proposed as an explanatory variable of job satisfaction, is a higher order concept representing the fundamental evaluations that people make about themselves and their environments. These evaluations are in connection with the persons' qualities, competences and potential. Core self-evaluations are comprised of four more specific lower-order traits: (1) SelfEsteem: the basic appraisal people make of themselves and the overall value that one places on one's self as a person; (2) Generalized Self-Efficacy: an estimate of one's fundamental ability to cope with life's exigencies, to perform, and to be successful; (3) Locus of Control: the degree to which individuals believe that they control events in their lives; and (4) Neuroticism: the tendency to have a negativistic cognitive/explanatory style and to focus on negative aspects of the self (Watson, 2000).

Beyond Job Satisfaction, Judge and colleagues related CSE to Life Satisfaction (Judge, Locke, Durham \& Kluger, 1998), Job Performance (Judge \& Bono, 2001), and motivation (Erez \& Judge, 2001; Judge, Erez, \& Bono, 1998). Judge et al. (1997) proposed that core self-evaluations affected the perception of objective conditions, events and the norms against which perceived conditions and events are appraised, which in turn influenced satisfaction judgments. Several studies have provided empirical support for the proposed relationship between core self-evaluations and Job Satisfaction. Heller and Judge (2002) found that core self-evaluations were more strongly related to Job Satisfaction than was Positive and Negative Affectivity or the personality traits and a meta-analysis by Judge and Bono (2001) reported that when the four traits were combined into a single composite measure, the overall core trait correlated .37 with Job Satisfaction. According to Judge, VanVianen and DePater (2004), the core self-evaluations concept is probably the best dispositional predictor of Job Satisfaction.

Most of the studies conducted with the CSE measured this concept in an indirect way. Indeed, the CSE concept had to be extracted by factor analyzing the four scales which compose it, Neuroticism, Locus of Control, Self-Esteem and General Self Efficacy. However, a direct measure of CSE termed Core SelfEvaluations Scale (CSES) has been recently developed (Judge, Erez, Bono \& Thoresen, 2003), suggesting that this measure is fairly reliable, with over .80 average alpha and test-retest reliabilities (Judge et al. 2003). In accordance with these assumptions, the CSE has been found to be significantly related to life, job and job performance satisfaction (Judge et al., 2003). In addition it should also be specified that the CSE predicts satisfaction and performance criteria much better than the indirect measure of the core self- evaluations through its four components (Judge et al., 1997, 2001). Nevertheless, the link between CSE with Life Satisfaction has rarely been assessed. Judge et al. (1997, 2003) did not explicitly discuss non-work life domains, but the same linking mechanisms should apply to satisfaction with non-work life domains as well (Rode, 2004). For instance, sport satisfaction may constitute an important life satisfaction domain, because sport and physical activities have 
received an increasing interest in our society where obesity and inactivity are becoming increasingly prevalent (US Department of Health and Human Services, 1996). Subjects who are more active in sports reported higher levels of satisfaction with life as a whole that the non-active ones (Melin, Fugl-Meyer \& FuglMeyer, 2003). In that sense the study on the influence of the dispositional variables in Sport Satisfaction and its links with Life Satisfaction, might provide additional evidence for the predictive influence of CSE.

The aims of the present study were to replicate the relationships obtained by Judge et al. (2003) between the Core SelfEvaluations Scale and Life Satisfaction, and to assess whether CSE was a better predictor of Life Satisfaction or Sport Satisfaction. In accordance to past results (Judge et al. 2003), we hypothesised a positive relation between CSE, Life Satisfaction and Sport Satisfaction. Considering the link between Life Satisfaction and others domains satisfaction, we also hypothesised a positive link between Life Satisfaction and Sport Satisfaction.

\section{Participants}

\section{Method}

Participants were three hundred and thirteen (231 men and 82 women $)$ with age ranging from 17 to $47\left(M_{\text {age }}=22.9\right.$ years, $S D_{\text {age }}=5.9$ years) who volunteered to participate in the study. Participants completed the French language version of the CSES, the Satisfaction with Life Scale and the Satisfaction with Sport Scale. All of them practice a sport three to five times a week and most played a game on the weekend. Half of the sample participated in a sport associated with a French National team, so that, they can be considered as semi-professionals.

\section{Measures}

The French language version of the Core Self-Evaluation Scale (CSES. Judge et al.,2003, adapted by Rolland, 2003 with authorization of the authors) is a twelve item ("Sometimes I feel depressed"; "I complete tasks successfully") scale containing six positively and six negatively worded items in a 5-point Likert scale ranging from $1=$ strongly disagree to $5=$ strongly agree. This scale measures a one-factor construct of Core SelfEvaluation. The Cronbach alpha of the English language CSES was .84 (Judge et al., 2003).

The Satisfaction with Life Scale (SWLS. Diener, Emmons, Larsen \& Griffins, 1985) was developed for the evaluation of general life satisfaction. Subjects responded to five affirmative sentences ("The conditions of my life are excellent"; "If I could live my life over, I would change almost nothing"). Reliability coefficient was .87 .

The Satisfaction with Sport Scale (SWSS). This scale was developed specifically for this study on the basis of Diener's SWLS (Diener et al., 1985) for the evaluation of general sport career satisfaction. This measure contains 5 items derived from the five-item Satisfaction with Life Scale (Diener et alt., 1985). Participants answered on a 7-point Likert scale ranging from strongly disagree (1) to strongly agree (7) to statements such as, "In most ways my sport life is close to ideal"; "I am satisfied with my sport life".

\section{Data analysis}

All analyses were done with SPSS 14 and Amos 7.00 (Arbuckle, 1999). We used structural equation modelling (SEM) to test our prospected models. To measure model fit, we relied on different fit indexes : the chi square $\left(c^{2}\right)$, the goodness-of-fit index $(G F I)$, the Tucker Lewis index $(T L I)$, the comparative fit index $(C F I)$, and the root mean square error of approximation (RMSEA). Rules of thumb are that GFI, CFI and TLI values of .90 represent a good fit and values of .95 or greater represent excellent fit (Hu \& Bentler, 1998). RMSEA values of .06 are thought to indicate a close fit, .08 a fair fit (Hu \& Bentler, 1998).

Three different models were tested in order to assess the contribution of the CSE in the prediction of Life and Sport Satisfaction following Byrne's (1993) suggestions. In the first model we fixed the relation between CSE and Sport Satisfaction to 0 to obtain the unique contribution of CSE to Life Satisfaction. In the second model, we fixed the relation between CSE and Life Satisfaction to 0 to obtain the unique contribution of CSE to Sport Satisfaction. In the third model, all the parameters were set free. Comparisons of these three competing models were provided by the $c^{2}$ difference test.

\section{Results}

Descriptive statistics, correlations and internal consistence

Descriptive statistics and intercorrelations are shown in Table 1. The kurtosis and skewness with values close to zero indicate that the data distributions for the three variables are normal. We obtained satisfactory reliability coefficient of .78 for the SWSS.

The correlation between SWLS and SWSS is large and positive, $r=.45$. In this study, significant correlations were found between CSES with SWLS $(r=.48)$ and SWSS $(r=.28)$.

Table 1

Descriptive statistics and correlations of observed indicators.

\begin{tabular}{lccccccc}
\hline Variables & $M$ & $S D$ & Kurtosis & Skewness & Alpha & CSES & SWLS \\
\hline CSES & 40.41 & 6.14 & -.39 & -.19 & .77 & & \\
SWLS & 23.04 & 5.47 & -.46 & .09 & .85 & $.48^{* *}$ & \\
SWSS & 22.58 & 5.07 & -.45 & -.14 & .76 & $.26^{* *}$ & $.45^{* *}$ \\
\hline
\end{tabular}

Note. ${ }^{* *} p<.01$. M: Media. SD: Standard Deviation. CSES: Core SelfEvaluation Scale. SWLS: The Satisfaction with Life Scale. SWSS: The Satisfaction with Sport Scale

\section{Confirmatory factor analysis (CFA)}

The variance-covariance matrix was analysed through the Maximum Likelihood estimation method. The first aim of the analysis was to confirm the one-factor structure (Figure1) obtained by Judge et al. (2003). Fit statistic for the CFA indicated a fair fit to the data $\left(\chi^{2}(d f)=106.76(51) ; G F I=0.95 ; T L I\right.$ $=.89 ; C F I=0.91 ; R M S E A=0.059)$, with significant parameter estimates at the $p<.001$ level. 
Table 2

Goodness-of-fit indices and beta weight for the estimated models.

\begin{tabular}{|c|c|c|c|c|c|c|c|c|c|}
\hline Model & Relations & $\beta$ & $R^{2}$ & $\chi^{2}$ & $d f$ & GFI & $T L I$ & CFI & RMSEA \\
\hline \multirow{2}{*}{ Model 1} & $\mathrm{CSES} \rightarrow \mathrm{SWLS}$ & $.54 * *$ & .29 & \multirow{2}{*}{395.38} & \multirow{2}{*}{202} & \multirow{2}{*}{.90} & \multirow{2}{*}{.89} & \multirow{2}{*}{.90} & \multirow{2}{*}{.06} \\
\hline & $\mathrm{CSES} \rightarrow$ SWSS & .00 & .00 & & & & & & \\
\hline \multirow{2}{*}{ Model 2} & $\mathrm{CSES} \rightarrow$ SWLS & .00 & .00 & \multirow{2}{*}{464.56} & \multirow{2}{*}{202} & \multirow{2}{*}{.89} & \multirow{2}{*}{.85} & \multirow{2}{*}{.87} & \multirow{2}{*}{.07 } \\
\hline & $\mathrm{CSES} \rightarrow \mathrm{SWSS}$ & .07 & .01 & & & & & & \\
\hline \multirow{2}{*}{ Model 3} & $\mathrm{CSES} \rightarrow$ SWLS & $.63 * * *$ & .39 & \multirow{2}{*}{371.24} & \multirow{2}{*}{201} & \multirow{2}{*}{.90} & \multirow{2}{*}{.90} & \multirow{2}{*}{.91} & \multirow{2}{*}{.05} \\
\hline & $\mathrm{CSES} \rightarrow$ SWSS & $.35 * *$ & .12 & & & & & & \\
\hline
\end{tabular}

$\overline{\text { Note. }{ }^{* *} p<.01 ; * * * p<.001 . c^{2} \text { : Chi square. GFI: Goodness-of-fit index. TLI: Tucker Lewis index. CFI: comparative fit index. RMSEA: Root mean }}$ square error of approximation. CSES: Core Self-Evaluation Scale. SWLS: The Satisfaction with Life Scale. SWSS: The Satisfaction with Sport Scale.

\section{Analysis of Structural Equation Models (SEM)}

Table 2 shows parameter estimates and fit indices for the three models. Fit statistics for the first model (Model 1) indicated a fair fit to the data $c^{2}=395.38(G F I=.90 ; T L I=.89$, $C F I=.90, R M S E A=.06)$ with a significant weight between CSE and Life Satisfaction $(\beta=.54, p<.01)$. The second model (Model 2) was not supported by the various fit indices, with a non significant association of CSE with Sport Satisfaction. In contrast, the third model fit well to data with $c^{2}=371.24$ (GFI $=.90 ; T L I=.90, C F I=.91, R M S E A=.05)$ with significant weights on both, Life Satisfaction $(\beta=.63, p<.001)$ and Sport Satisfaction $(\beta=.35, p<.01)$. In this model, the CSE explained $39 \%$ of Life Satisfaction and $12 \%$ of Sport Satisfaction variances.

There was a significant $\left(\Delta c^{2}\right.$ test between model 1 and model 3; $\left.\Delta c^{2}=395.38-371.24=24.14, p<.01\right)$ suggesting that the introduction of Sport Satisfaction in the relations between CSES and Life Satisfaction provide better fit to the data over

Figure 1

Confirmatory factor analysis of the CSES.

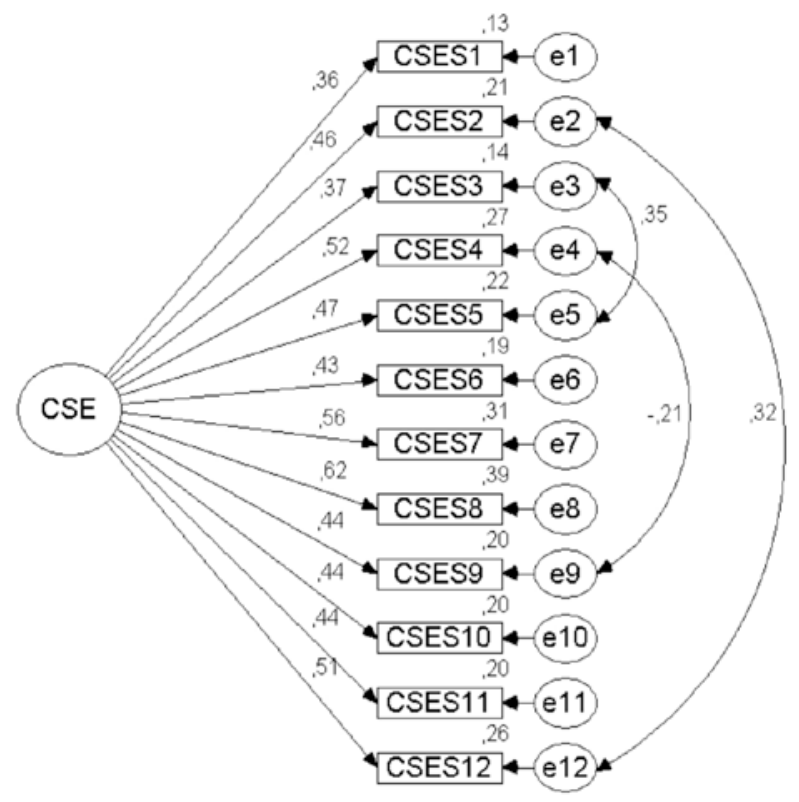

and above Model 1. These results indicate that CSES is a better predictor of life than sport satisfaction, and that sport satisfaction might actually constitute another satisfaction dimension that deserves being explored in life satisfaction studies.

\section{Discussion}

In this study, we tried to replicate the results obtained by Judge et al. (2003) in a sport -oriented sample and by extension, to explore the link between CSE and Sport Satisfaction, a specific domain of life satisfaction. The relation between the direct measure of the CSE concept and Life Satisfaction has not been studied since the validation of this measure (Judge et al., 2003), where a positive correlation between CSE and Life and Job Satisfaction was found. This relation confirmed that the way people see themselves influence in turn the way they experience their lives. The link obtained between the CSE and Sport Satisfaction is also an additional argument in favour of the dispositional influence of the CSE concept on satisfaction (Judge et al., 2003). According to Rojas (2006) there is a general consensus on the relationship between a person's life satisfaction and his or her satisfaction in different areas of life. The correlation between Life and Sport Satisfactions reinforces this well known relation, an outcome that is also consistent with

Figure 2

Structural model of relations between CSES, SWLS and SWSS.

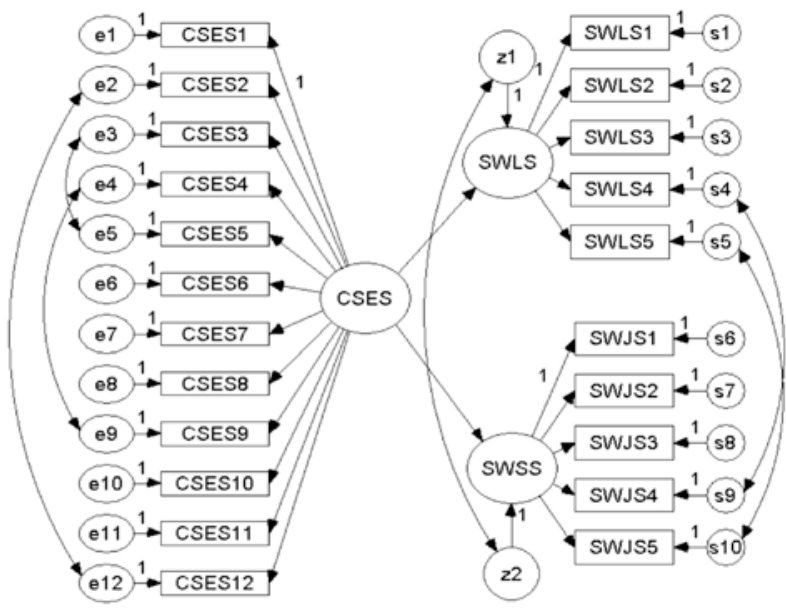


previous studies on the relation between Life Satisfaction and domains satisfaction. The relationship between Life Satisfaction and Sport Satisfaction are strong $(r=.45)$. Nevertheless the relationships of these two variables with the Core Self-Avaluation present different relationship (.48 and .26), although both correlations are significant. Notice that the .45 correlation implies around $20 \%$ of the accounted variance. According to Andrews and Withey (1976) we understand that the Life Satisfaction is a more general variable and Sport Satisfaction is a more specific domain.

The results in the present study suggest that CSE is indeed a good predictor of Life Satisfaction (model 1) but not of Sport Satisfaction if we considered the poor fit of the model 2. Early research noted that the effects of domain satisfactions on life satisfaction appear to be additive, with the most salient life domains explaining most variance of Life Satisfaction (Andrews \& Withey, 1976; Campbell et al., 1976). In this study however, sport domain was a very important one for all participants. This might explain why the model 3 yielded the best model fit, which included Sport Satisfaction into the relation between CSE and Life Satisfaction. The difference with model 1 was significant, showing that it is important to study the Sport Satisfaction as a domain in relation with the general satisfaction. These results might suggest that Top-Down models have considerable merit in explaining life satisfaction but that domains of satisfaction might also need to be taken into account in comprehensive models of satisfaction (Heller, Watson \& Illies, 2004). It could be argued that the model fit of model 3 would have been worse with a sample not so focussed into the sport realm. Research on the dispositional sources of life satisfaction has made important strides in recent years. The current study has one limitation: the sample is quite small for a study of questionnaires and women are not enough represented. For future studies it would be important to equilibrate both sexes. Moreover, it would be interesting to include more age groups in order to study the differences between them; and to include a control group to distinguish and compare between types and modalities referred to sport. In line with the theoretical recommendations in the satisfaction literature, future studies could use a more integrative perspective including various life domains in addition to sport, in addition to considering other personality dimensions such as the Big Five (McCrae \& Costa, 1995).

\section{References}

1. Andrews, F.A. \& Withey, S.B. (1976). Social indicators of well-being in America: The development and measurement of perceptual indicators. New York: Plenum Press. http:// dx.doi.org/10.1007/978-1-4684-2253-5

2. Byrne, B.M. (1993). The Maslach Burnout Inventory: Validating factorial structure and invariance across elementary, intermediate, and secondary teachers. Journal of Occupational and Organizational Psychology, 66,197-213. http:// dx.doi.org/10.1111/j.2044-8325.1993.tb00532.x

3. Campbell, A., Converse, P.E. \& Rodgers, W.L. (1976). The quality of American life: perceptions, evaluations and satisfaction. New York: Sage Foundation.

4. Diener, E. (1984). Subjective Well-Being. Psychological Bulletin, 95, 542-575. http://dx.doi.org/10.1037/00332909.95.3.542

5. Diener, E., Emmons, R. A. \& Larsen, R. J. (1985). The Satisfaction With Life Scale. Journal of Personality Assessment, 49, 71-75. http://dx.doi.org/10.1207/s15327752jpa4901_13

6. Dubin, R. (1956). Industrial workers' worlds: The 'Central Life Interests' of industrial workers. Journal of Social Issues, 3, 131-42.

7. Erez, A. \& Judge, T. A. (2001). Relationship of core selfevaluations to goal setting, motivation, and performance. Journal of Applied Psychology, 86, 1270-1279. http:// dx.doi.org/10.1037/0021-9010.86.6.1270

8. Heller, D., Judge, T.A. \& Watson, D. (2002). The confounding role of personality and trait affectivity in the relationship between job and life satisfaction. Journal of Organizational Behavior, 23, 815-835. http://dx.doi.org/10.1002/ job. 168

9. Heller, D., Watson, D. \& Ilies, R. (2004). The Role of Person versus Situation in Life Satisfaction: A Critical Examination. Psychological Bulletin, 130, 574-600. http:// dx.doi.org/10.1037/0033-2909.130.4.574

10. Hu, L. \& Bentler, P.M. (1998). Fit indices in covariance structure modelling: sensitivity to under parameterized model misspecification. Psychology Methods, 3, 424-453. http://dx.doi.org/10.1037/1082-989X.3.4.424

11. Judge, T.A. \& Bono, J.E. (2001). Relationship of core self-evaluations traits-self esteem, generalized selfefficacy, locus of control, and emotional stability-with job satisfaction and job performance: A meta-analysis. Journal of Applied Psychology, 86, 80-92. http://dx.doi. org/10.1037/0021-9010.86.1.80

12. Judge, T.A., Erez, A. \& Bono, J.E. (1998). The power of being positive: The relationship between positive self-concept and job performance. Human Performance, 11, 167187. http://dx.doi.org/10.1080/08959285.1998.9668030

13. Judge, T.A., Erez, A., Bono, J.E. \& Thoresen, C.J. (2003). The core self-evaluations scale: development of a measure. Personnel Psychology, 56, 303-331. http://dx.doi. org/10.1177/0013164409344505

14. Judge, T.A., Locke, E.A. \& Durham, C.C. (1997). The dispositional causes of job satisfaction: A core evaluations approach. Research in Organizational Behavior, 19, 151188. http://dx.doi.org/10.1002/job.358

15. Judge, T.A., Locke, E.A., Durham, C.C. \& Kluger, A.N. (1998). Dispositional effects on job and life satisfaction: the role of core evaluations. Journal of Applied Psychology, 83, 17-34. http://dx.doi.org/10.1037/0021-9010.83.1.17

16. Judge, T.A., Van Vianen, A.E.M. \& De Pater, I.E. (2004). 
Emotional stability, core self-evaluations, and job outcomes: A review of the evidence and an agenda for future research. Human Performance, 17, 325-346. http://dx.doi. org/10.1207/s15327043hup1703 4

17. Lykken, D. \& Tellegen, A. (1996). Happiness is a stochastic phenomenon. Psychological Science, 7, 186-189. http:// dx.doi.org/10.1111/j.1467-9280.1996.tb00355.x

18. Lyubomirsky, S., Sheldon, K.M. \& Schkade, D. (2005). Pursuing Happiness: The architecture of sustainable change. Review of General Psychology, 9, 111-113. http:// dx.doi.org/10.1037/1089-2680.9.2.111

19. McCrae, R. R. \& Costa, P. T., Jr. (1995). Traits explanations in personality psychology. European Journal of Personality, 9, 231-252. http://dx.doi.org/10.1002/per.2410090402

20. Melin, R., Fugl-Meyer, K. S. \& Fugl-Meyer, A. R. (2003). Life satisfaction in 18-to 64-year-old Swedes: in relation to education, employment situation, health and physical activity. Journal of Rehabilitation Medicine, 35, 84-90. http:// dx.doi.org/10.1080/16501970306119

21. Rice, R.W., McFarlin, D.B., Hunt, R.G. \& Near, J.P. (1985). Organizational work and the perceived quality of life: Toward a conceptual model. Academy of Management Review, 10, 296-310.

22. Rode, J.C. (2004). Job satisfaction and life satisfaction revisited: A longitudinal test of an integrated model. Human Relations, 57, 1205-1230. http://dx.doi. org/10.1177/0018726704047143
23. Rojas, M. (2006). Life satisfaction and satisfaction in domains of life: is it a simple relationship? Journal of Happiness Studies, 7, 467-497. http://dx.doi.org/10.1007/ s10902-006-9009-2

24. Rolland, J.P. (2000). Le bien-être subjectif: revue de question. Pratiques Psychologiques, 1, 5-21.

25. SPSS 14 and Amos 7.0 for Windows, 2007. Chicago: SPSS Inc.

26. Steel, P., Schmidt, J. \& Shultz, J. (2008). Refining the relationship between personality and subjective wellbeing. Psychological Bulletin, 134, 138-161. http://dx.doi. org/10.1037/0033-2909.134.1.138

27. US Department of Health and Human Services. Physical activity and health: a report of the surgeon general. US Department of Health and Human Services, Center for Disease Control and Prevention, National center for Chronic Disease Prevention and Health Promotion : Atlanta, GA; 1996.

28. Watson, D. (2000). Mood and temperament. New York: Guilford.

Received 6 March 2014

Received in revised form 19 June 2014

Accepted 25 July 2014 